\section{Passing the Torch}

\author{
James K. Drennen III ${ }^{1}$
}

Published online: 17 February 2020

(C) Springer Science+Business Media, LLC, part of Springer Nature 2020

Since the fall of 2006, the Journal of Pharmaceutical Innovation has provided quality scientific publications on topics covering important current issues ranging from "R\&D to Market." I am delighted to announce that Dr. Stephen Scypinski, engaged with the journal since its beginning as a co-editor, will take over as the new Editor-inChief. Steve, a recognized leader in our industry, is well familiar with all aspects of journal management and our readers can anticipate a seamless transition. I look forward to continuing service with JOPI as a member of the Editorial Advisory Board.

It has been an honor to serve the journal as editor and I offer my sincere thanks to the many individuals who have played critical roles in the journal's success. From the original support by ISPE, Elsevier, and the FDA to create the journal; to current and past board members; to the editorial staff at Springer;
I am grateful for the support of many committed people who have shared a passion for JOPI. To the many individuals who have served the journal as referees, I recognize your significant commitment. Of course, I cannot forget to thank our readers and ask for your continued support; the editorial team and advisory board will enthusiastically accept any comments or ideas that you may provide.

Finally, I wish to acknowledge my deep respect for those who have served on our editorial team, including Wilson Meng, John Bobiak, Doug Both, and, of course, Steve Scypinski. These individuals have defined the nature and quality of the journal with their technical expertise, dedication, and vision.

With Gratitude,

Jim

Publisher's Note Springer Nature remains neutral with regard to jurisdictional claims in published maps and institutional affiliations.
James K. Drennen, III

drennen@duq.edu

1

Duquesne University, Pittsburgh, PA, USA 